Version del autor

Pre-print

\title{
STAKEHOLDER ENGAGEMENT TO EVALUATE TOURIST DEVELOPMENT PLANS WITH A SUSTAINABLE APPROACH ${ }^{1}$
}

\author{
Hannia Gonzalez-Urango ${ }^{1,2}$ \\ Mónica García-Melón ${ }^{1}$ \\ ${ }^{1}$ Ingenio (CSIC-UPV), Universitat Politècnica de València, Valencia, Spain \\ ${ }^{2}$ Universidad Simón Bolívar, Barranquilla, Colombia
}

\begin{abstract}
In this paper, an evaluation of tourist development plans in the city of Cartagena de Indias (Colombia) is analyzed. Different stakeholders are involved in the search for solutions to this problem. The proposal is based on a model that combines multicriteria decision analysis and participatory procedures. This is done using a combination of two techniques, namely the Analytic Network Process (ANP) and the Social Network Analysis (SNA). Thus, a systematic course of analysis of the alternatives under examination and of the different stakeholders who participate is provided. The application of SNA will analyze the influence among stakeholders. The ANP will allow prioritizing the tourist development plans. The results obtained in this work allow concluding that the combination SNA-ANP is a suitable tool for strategic planning of a city.
\end{abstract}

KEYWORDS: Social network analysis (SNA), Analytic Network Process (ANP), participatory decision making, Cartagena de Indias, tourist strategic, sustainable evaluation.

\section{INTRODUCTION}

\subsection{Cartagena de Indias and its tourist planning process}

Tourism is a great industry that is currently going through a period of great relevance. The sector accounts for $10 \%$ of world's GDP, $7 \%$ of the global trade and creates one in every 10 jobs (World Tourism Organization, 2017). According to UNWTO, these figures are expected to keep rising especially in emerging economic destinations, such as South America (Mariani et al., 2014; UNWTO, 2014; UNWTO, 2017).

\footnotetext{
1 "This is the pre-peer reviewed version of the following article: [Gonzalez-Urango H, García-Melón M. Stakeholder engagement to evaluate tourist development plans with a sustainable approach. Sustainable Development. 2018;1-12. https://doi.org/10.1002/sd.1849], which has been published in final form at [https://doi.org/10.1002/sd.1849]. This article may be used for non-commercial purposes in accordance with Wiley Terms and Conditions for Use of Self-Archived Versions."
} 
This trend of tourism growth comes with some drawbacks which include an increasing pressure on the territories (Berzina et al., 2015). The tourism sector can and is firmly committed to playing its part in the 2030 Sustainable Development Agenda. Promoting governments, the private sector, academia and the civil society are expected to work together in order to implement sustainable tourism activities with an emphasis on sustainable land use (UNWTO, 2017).

Colombia as an emerging destination and Cartagena de Indias as its most representative and important destination cannot be left behind when it comes to achieve this aim. This city has to prepare and to adapt public policies and managerial strategies to face new challenges and opportunities both for the tourist industry and for the destinations. Challenges related to the increasing competition among tourist destinations; the modification of the target markets for established tourist destinations; the increasing importance of collaboration (Mariani et al., 2014; Wang et al., 2016) and integrating sustainable planning (Dvarskas, 2017).

For several years, the city has been doing long-term planning, which. has not yet evolved to deal with upcoming challenges such as those of the sustainable development. Environmental perception and attitude of stakeholders generate debates, controversy and contradictions among economic sectors and groups.

In this paper, we will focus in bringing some light to solve this problem. For that we propose to evaluate the different tourist strategic plans that the city has currently in mind considering sustainable criteria together with integrative and participative approach supported by technical and scientific knowledge (Loken 2007; Alves et al., 2013; Le Pira et al., 2016). This is a decision-making problem that should be approached from the multi-criteria analysis perspective, with the participation of different stakeholders.

\subsection{The participation of stakeholders in the evaluation process}

Due to the complexity and interrelations of the problems caused by global society (economic development, natural resource management, among others) public policy managers must conduct a stakeholder analysis to identify and take account of the individuals, groups and organizations involved in or affected by such policies (Bryson, 2004). Effective use of stakeholders requires that the decision-makers use them in the right place, use the right stakeholders, elicit information from them in a rigorous way, and apply appropriate analysis techniques to the elicited information (Glicken, 2000)..

Several approaches have been proposed to investigate the relationships among stakeholders, like power versus interest grids, stakeholder salience (Mitchell et al., 2009), interrelationship diagrams (Bryson, 2004), or actor-linkage matrices (Biggs \& Matsaert, 1999). However, these techniques do not allow determining an individual value of the influence of each actor in a decision-making process. 
There is, thus, one technique Social Network Analysis (SNA) (Wasserman \& Faust, 2007), based on the graph theory, which allows to determine this individual value. Through SNA we can analyze flows of knowledge in the network. The position of the participant in the network, that is his/her centrality, is the most commonly index used to analyze his/her influence (Ahmedi et al., 2017).

\subsection{The multicriteria evaluation approach}

The selection and interpretation of the sustainable criteria, in the evaluation of the different tourist strategic plans that Cartagena has currently in mind should be done carefully to maximize the correlation between the index values obtained and the quality to be measured. Multicriteria Decision Aid (MCDA) techniques are appropriate to solve this type of problems. General information about MCDA can be found in BarbaRomero and Pomerol (1997), Belton and Stewart (2002) and Loken (2007).

Several authors introduce the use of MCDA techniques for Sustainable Assessment. Many of them focus on the use of the Analytic Hierarchy Process (AHP; Saaty 1990), which has been accepted as a leading multicriteria decision model (Sólnes, 2003; Ramzan et al., 2008; Šijanec et al., 2009; Akbari et al., 2017) to assign priorities to the criteria or indicators involved. In our case we propose a more evolved technique namely the Analytic Network Process (ANP). The ANP is a method proposed by Saaty to generalize his original AHP in situations of interdependence and feedback among the decision elements. A detailed description of the method can be found in Saaty (2001).

Evidence regarding the use of ANP for the tourism development has been found in (Chen et al., 2009; Garcia-Melon et al. 2010; Aminu et al., 2013; Jeong et al., 2014; Bramwell, 2015; Bonzanigo et al., 2016). Besides ANP has been integrated with other tools such as (GIS) for sustainable tourism planning (Aminu et al., 2013; Aminu et al., 2017); with Delphi as an environmental assessment tool of sustainable tourist strategies (García-Melón et al., 2012); and Hybrid SWOT - ANP - Fuzzy ANP model for prioritization strategies of sustainable development of ecotourism (Arsić et al., 2017).

The use of the ANP for this purpose is novel since currently, the decision-making processes in the city of Cartagena are tackled in a little structured and participative way. It is therefore vital to explore new prioritization tools that contribute to show greater coherence in the selection and public justification of the actions to be taken (Peris et al., 2013).

In this paper we propose a methodology based on the combination of two techniques: SNA to assess the relationships among stakeholders by identifying the most relevant ones and ANP to aggregate their opinions and evaluate the tourist strategic plans of Cartagena in order to improve the tourist offer of the city. The aim being to verify in practice the relevance and usefulness of the methodology in planning process and to draw some conclusions on their potentialities and limitations. 


\section{METHODOLOGY PROPOSED}

The steps followed in the methodology are shown in Figure 1 and a detailed description and the methodology implementation is presented in the case study in next sections.

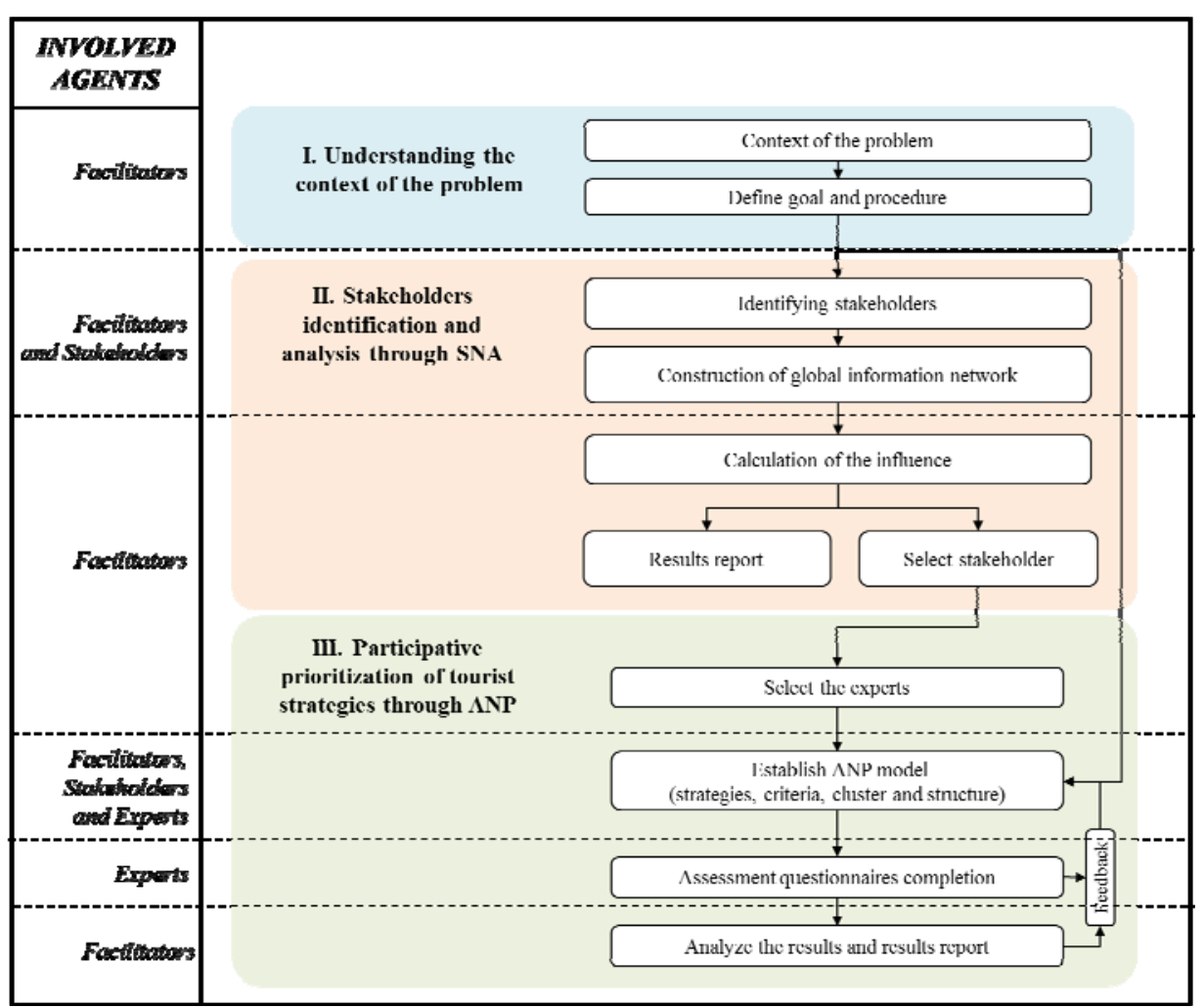

Figure 1. Methodology proposed

The application of this methodology is organized in three main stages:

- Understanding the context of the problem

- Stakeholders identification and analysis through SNA

- Participative prioritization of tourist strategies through ANP

\section{CASE STUDY. PRIORITIZING TOURIST DEVELOPMENT PLANS IN THE CITY OF CARTAGENA}

\subsection{Understanding the context of the problem}

After the revision of local and regional plans, international experiences, and a literature review (Comisión Regional de Competitividad de Cartagena y Bolívar, 2010; Alcaldía Distrital de Cartagena de Indias D. T. y C., 2014; Alcaldía Distrital de Cartagena de Indias D. T. y C., 2016) three proposals (alternatives) were selected, with the help of the Local Tourist Office and some experts. Alternatives are comparable between them and are aimed at developing new urban projects in the city. Prioritizing these proposals should allow channeling most of this sector's development and resources, and should help improving the touristic offer of the city. 
The selected alternatives are:

- Alternative 1: A1. Tourist complex. Develop an area where tourist facilities are comprehensively established for various purposes of tourism and relaxation, mainly eco-activities. Located in insular territory consistent with geographical and cultural conditions.

- Alternative 2: A2. Tourist boulevard. Develop a coastal protection to improve the connection and spaces between the most relevant tourist neighborhoods and the airport.

- Alternative 3: A3. Waterborne transport system. Develop a network of public transportation system using the water resources available around the city.

Until now, the programs and actions declared in the different plans and programs mentioned above have been prioritized according to the concerns and capacities of the participants. The lack of inclusion and use of more structured techniques for the definition of the Action Plan are the main factors favoring the use of multicriteria multistakeholder prioritization techniques.

\subsection{Stakeholders identification and analysis through SNA}

The first step was the identification of stakeholders. An initial review of secondary sources (Alcaldía Distrital de Cartagena de Indias D. T. y C., 2014; Corpoturismo, 2015, The National Colombian Tourist Register RNT), and a "snowball technique" were used. Following the method proposed by Varvasovszky \& Brugha (2000); Reed et al. (2009); and Saint Ville et al (2017).

A list of 45 actors was identified among institutions, organizations and groups. A questionnaire to analyze the amount of information exchanged was sent to all of them (Error! Reference source not found.). According to Hanneman et al (2005) the sharing of information can be used to establish links between two nodes in a social network. Our model is based on the analysis of information exchange among stakeholders.

Table 1. Example of the questionnaire for stakeholder A1. Local Government

\begin{tabular}{|c|c|c|c|c|}
\hline \multicolumn{5}{|c|}{$\begin{array}{l}\text { Regarding tourist sector management, with which of the following actors have you exchanged } \\
\text { information? How often? }\end{array}$} \\
\hline Actor & $\begin{array}{l}\text { Do you send } \\
\text { information to } \\
\text { him/her? }\end{array}$ & $\begin{array}{l}\text { How often? } \\
\text { (Daily, weekly, } \\
\text { monthly ...) }\end{array}$ & $\begin{array}{c}\text { Do you receive } \\
\text { information from } \\
\text { him } / \text { her? }\end{array}$ & $\begin{array}{l}\text { How often? } \\
\text { (Daily, weekly, } \\
\text { monthly...) }\end{array}$ \\
\hline \multicolumn{5}{|l|}{ Local Tourist Office } \\
\hline \multicolumn{5}{|l|}{ Local Planning Office } \\
\hline \multicolumn{5}{|l|}{$\begin{array}{l}\text { Local Institute of Heritage and } \\
\text { Cultural }\end{array}$} \\
\hline$\ldots$ & & & & \\
\hline
\end{tabular}

We gathered answers from 43 actors (Error! Reference source not found.). The information gathered was scaled in the following way: Zero means none information 
exchange, one means an exchange at least every two months, and two means that the information exchange is monthly or more frequently.

Table 2. List of stakeholders and Multiple Centrality Measures

\begin{tabular}{|c|c|c|c|c|c|c|}
\hline \multirow[t]{2}{*}{ ID } & \multirow[t]{2}{*}{ Actors } & \multicolumn{2}{|c|}{$\begin{array}{l}\text { Freeman } \\
\text { Degree }\end{array}$} & \multicolumn{2}{|c|}{ Closeness } & \multirow[t]{2}{*}{ Betweenness } \\
\hline & & Out & In & Out & In & \\
\hline A1 & Local Government & 25 & 23 & 68 & 71 & 37,49 \\
\hline$A 2$ & Local Tourist Office & 66 & 58 & 46 & 53 & 376,53 \\
\hline A3 & Local Planning Office & 4 & 4 & 85 & 90 & 0,17 \\
\hline A4 & Local Institute of Heritage and Cultural & 23 & 19 & 66 & 75 & 21,36 \\
\hline A5 & Departmental (Regional) Tourist Office & 34 & 33 & 61 & 65 & 58,78 \\
\hline$A 6$ & Ministry of Commerce, Industry and Tourism & 23 & 22 & 69 & 74 & 13,00 \\
\hline A7 & $\begin{array}{l}\text { Colombian Agency for the Promotion of Exports, } \\
\text { Tourism and Investment }\end{array}$ & 35 & 31 & 63 & 71 & 21,02 \\
\hline$A 8$ & National Tourism Promotion Office & 43 & 38 & 58 & 66 & 72,73 \\
\hline$A 9$ & Local Chamber of Commerce & 47 & 42 & 56 & 6 & 118,12 \\
\hline A1 & Hotel Association A & 21 & 17 & 71 & 77 & 8,82 \\
\hline A11 & Hotel Association B & 16 & 13 & 76 & 80 & 1,70 \\
\hline$A 12$ & Travel Agency Association & 18 & 16 & 73 & 78 & 2,69 \\
\hline$A 13$ & Restaurant Association & 11 & 9 & 80 & 85 & 0,91 \\
\hline A14 & Society for local heritage & 17 & 12 & 76 & 83 & 15,74 \\
\hline A15 & $\begin{array}{l}\text { Colombian Association of Micro, Small and Medium } \\
\text { Enterprises (Bolivar) }\end{array}$ & 5 & 4 & 93 & 95 & 0,27 \\
\hline A16 & National Federation of Merchants (Bolivar) & 5 & 8 & 83 & 85 & 1,18 \\
\hline A17 & Professional group of tourist guides & 9 & 6 & 80 & 91 & 0,45 \\
\hline A18 & Other associations, groups or guild. & 6 & 6 & 82 & 87 & 0,54 \\
\hline$A 19$ & Local Airport & 12 & 8 & 77 & 85 & 1,32 \\
\hline$A 2$ & Cruise terminal & 25 & 17 & 66 & 77 & 21,41 \\
\hline$A 21$ & Museums & 19 & 11 & 71 & 81 & 5,04 \\
\hline A22 & Hotels & 36 & 39 & 57 & 59 & 146,01 \\
\hline$A 23$ & Tour Operators & 29 & 29 & 63 & 65 & 51,17 \\
\hline$A 24$ & Tour Operator A & 29 & 44 & 68 & 62 & 66,71 \\
\hline$A 25$ & Tourist Guides & 16 & 14 & 76 & 80 & 5,96 \\
\hline A26 & Promotion Websites & 16 & 11 & 74 & 81 & 42,55 \\
\hline A27 & Local transporters & 12 & 10 & 79 & 82 & 0,87 \\
\hline A28 & Restaurants and similars & 26 & 24 & 70 & 74 & 32,84 \\
\hline$A 29$ & University-Business-State Committee & 8 & 14 & 78 & 75 & 4,06 \\
\hline A3 & University A & 21 & 29 & 70 & 64 & 115,58 \\
\hline A31 & University B & 11 & 17 & 82 & 74 & 21,17 \\
\hline A32 & University $\mathrm{C}$ & 8 & 22 & 79 & 70 & 5,83 \\
\hline A33 & University D & 26 & 28 & 66 & 68 & 48,14 \\
\hline A34 & Research Institutes and Centers & 19 & 25 & 70 & 68 & 44,66 \\
\hline A35 & Environmental Institutions & 11 & 22 & 82 & 74 & 5,68 \\
\hline A36 & NGOs & 6 & 7 & 87 & 88 & 0,69 \\
\hline
\end{tabular}




\begin{tabular}{|c|l|cc|cc|c|}
\hline \multirow{2}{*}{ ID } & \multicolumn{1}{|c|}{ Actors } & \multicolumn{2}{c|}{$\begin{array}{c}\text { Freeman } \\
\text { Degree }\end{array}$} & \multicolumn{2}{c|}{ Closeness } & Betweenness \\
& & Out & In & Out & In & \\
\hline A37 & NGO A & 2 & 4 & 111 & 102 & 0,15 \\
A38 & NGO B & 10 & 3 & 76 & 91 & 1,82 \\
A39 & Insular Community Representative & 7 & 5 & 79 & 88 & 0,57 \\
A4 & Other Communities Representative & 12 & 9 & 77 & 81 & 2,28 \\
A41 & Civil Society Groups & 2 & 12 & 115 & 77 & 1,37 \\
A42 & Citizen & 0 & 5 & 168 & 82 & 0,00 \\
A43 & Other Institutions/actors & 7 & 8 & 86 & 79 & 3,64 \\
\hline
\end{tabular}

The 43 actors analyzed created the network which was introduced in software program UCINET@. The nodes' centrality based on: degree, closeness, and betweenness (Prell et al., 2009; Yang, 2014) was chosen as the most appropriate SNA indicator to assess the relevance of the stakeholders. The centrality indices of the actors were calculated (Error! Reference source not found.). The graphical representation of the whole information exchange network is shown in Error! Reference source not found. using the results of Betweenness centrality. This measure allows us to establish clearer differences among actors. The bigger the size of the geometric figure, the higher the betweenness centrality.

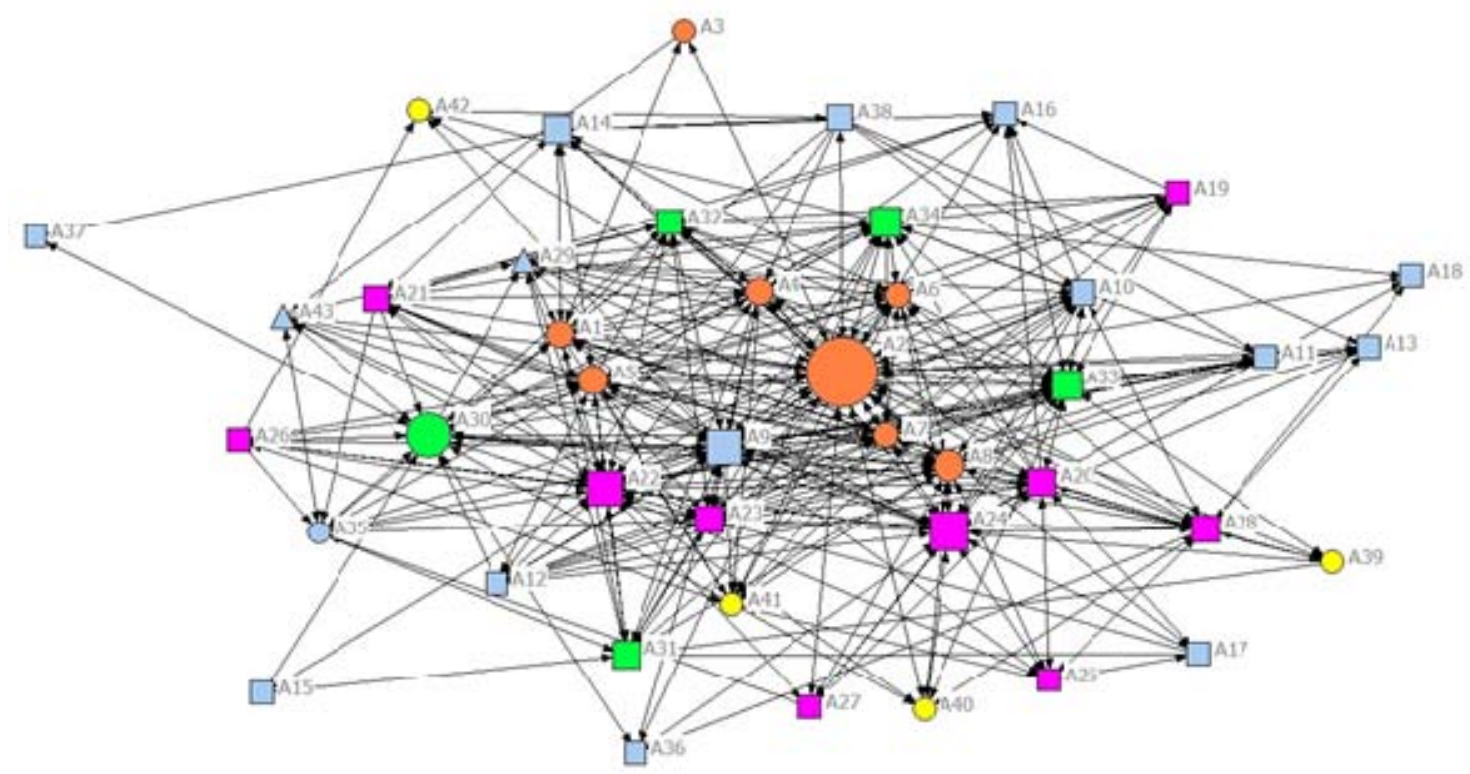

Figure 2. Graphs showing social network of stakeholders - According to Betweenness

The analysis of the network as a whole shows that it is a very dense network, given the number of actors and the number of connections that are observed. All the actors are connected by more than one connection, which denotes good communication within the network. We can also stand out that the local tourist sector has strong ties, which means that it is a consolidated sector and able to respond quickly and effectively. 
In order to select the most influential actors, we decided to select those with higher betweenness centrality. They are the ones who would have more control on the network, because more information will pass through them (Bodin \& Crona, 2009; Mok et al., 2017; Yamaki, 2017). According to this measure, the most influential actors are:

1. The Local Tourist Office (A2): Institution in charge of the planning and management of the tourist development of the city. It is the most relevant authority in terms of tourisT management.

2. Hotels (A22): One of the most important and relevant tourist services providers. The city has at least 530 hotels and two main associations.

3. Local Chamber of Commerce (A9): Is a private non-profit institution whose primary purpose is to promote regional development.

4. University A (A30): It is the only public University in the city.

5. National Tourist Promotion Office (A8): National institution created for the promotion of tourism and its competitiveness.

Once the list of relevant actors has been obtained, we have our preliminary list of experts for the ANP process. However, in order to follow the suggestions proposed by some scholars (Bodin et al., 2006; Prell et al., 2009) aimed at making the group of experts more resilient and adaptative to environmental changes, we have included two more actors who were not considered central, but were willing to collaborate in this process.

6. Social group leader (A41)

7. International expert (A43)

The next stages of the proposed methodology were carried out with the collaboration of the seven actors acting as experts.

\subsection{Participative prioritization of tourist strategies through ANP}

This part aims to support the experts chosen to evaluate and prioritize sustainable tourist strategies. The three proposals to be analyzed have been described in section 3.1: Tourist complex (A1), Tourist boulevard (A2) and Waterborne transport system (A3).

\subsubsection{Selection of evaluation criteria}

Following the ANP procedure, the criteria to evaluate the proposed alternatives were identified. It was necessary to make sure that these criteria could be grouped, that they were relevant, not redundant and easy to understand for the different actors. The final list of 25 criteria grouped in five evaluation clusters (Error! Reference source not found.) was defined based on a bibliographic review (Eldrandaly \& AL-Amari, 2014; Mariani et al., 2014; Jeong et al., 2014; Groselj \& Stirn, 2015; Liu \& Chou, 2016; Wang et al., 2016; Chen \& Bau, 2016) and with the assistance of the experts (Liu \& Chou, 2016). 
Version del autor

Pre-print

\begin{tabular}{|c|c|c|}
\hline Cluster & Criteria & Definition \\
\hline \multirow{2}{*}{$\begin{array}{l}\text { C.1 } \\
\text { Enviromental }\end{array}$} & $\begin{array}{l}\text { C } 1.1 \text { Use of heritage } \\
\text { and natural spaces }\end{array}$ & $\begin{array}{l}\text { The use of monuments, buildings, spaces and natural areas, } \\
\text { especially those considered as heritage }\end{array}$ \\
\hline & $\begin{array}{l}\text { C } 1.2 \text { Environmental } \\
\text { Risk and threats }\end{array}$ & $\begin{array}{l}\text { Actual or potential threat of adverse effects transmitted } \\
\text { through environmental conditions i.e. Erosion, sea levels } \\
\text { rise, swell, floods... }\end{array}$ \\
\hline \multirow{7}{*}{$\begin{array}{l}\text { C.2 Socio- } \\
\text { cultural }\end{array}$} & C 2.1 Qualified labor & $\begin{array}{l}\text { Training and skills required to implement and support } \\
\text { alternatives. }\end{array}$ \\
\hline & $\begin{array}{l}\text { C } 2.2 \text { Available } \\
\text { infrastructure and Public } \\
\text { services }\end{array}$ & $\begin{array}{l}\text { The existing basic systems and services, such as transport, } \\
\text { routes and public services. }\end{array}$ \\
\hline & $\begin{array}{l}\text { C } 2.3 \text { Integration of } \\
\text { ethnic groups }\end{array}$ & $\begin{array}{l}\text { To allow native communities and ethnic groups to } \\
\text { participate. }\end{array}$ \\
\hline & $\begin{array}{l}\text { C 2.4 Exploitation of } \\
\text { cultural identity }\end{array}$ & The use of elements of cultural identity \\
\hline & C 2.5 Quality of life & The beneficial effects of alternatives in the city. \\
\hline & $\begin{array}{l}\text { C } 2.6 \text { Linking to post- } \\
\text { conflict }\end{array}$ & $\begin{array}{l}\text { The possibility of linking alternatives with current post- } \\
\text { conflict processes. }\end{array}$ \\
\hline & $\begin{array}{l}\text { C } 2.7 \text { Associativity } \\
\text { among actors }\end{array}$ & $\begin{array}{l}\text { Degree of coordination and integration of the involved } \\
\text { actors in the city. }\end{array}$ \\
\hline \multirow{7}{*}{ C.3 Sectorial } & C 3.1 Origin of visitors & Origin of tourist arrivals in the city. \\
\hline & $\begin{array}{l}\text { C } 3.2 \text { Visitor } \\
\text { expenditure }\end{array}$ & Tourist spending particularly related to each alternative. \\
\hline & $\begin{array}{l}\text { C } 3.3 \text { Length of stay of } \\
\text { visitors }\end{array}$ & $\begin{array}{l}\text { Tourists' trip duration (nights, hours...), particularly related } \\
\text { to each alternative. }\end{array}$ \\
\hline & $\begin{array}{l}\text { C } 3.4 \text { Positioning in } \\
\text { national and } \\
\text { international markets }\end{array}$ & $\begin{array}{l}\text { Perceptions of the city in national and international } \\
\text { segments of tourism. }\end{array}$ \\
\hline & $\begin{array}{l}\text { C } 3.5 \text { Global Tourism } \\
\text { Trend }\end{array}$ & Preferences and world tourism tendency. \\
\hline & $\begin{array}{l}\text { C } 3.6 \text { Integration with } \\
\text { other destination }\end{array}$ & $\begin{array}{l}\text { The possibility to connect the city with regional } \\
\text { destinations. }\end{array}$ \\
\hline & $\begin{array}{l}\text { C } 3.7 \text { Experiential } \\
\text { Content } \\
\end{array}$ & $\begin{array}{l}\text { A closer bond between the visitor and the city created by } \\
\text { memorable experiences. }\end{array}$ \\
\hline \multirow{4}{*}{$\begin{array}{l}\text { C.4 } \\
\text { Economic- } \\
\text { Productive }\end{array}$} & $\begin{array}{l}\text { C } 4.1 \text { Promoting other } \\
\text { economic activities }\end{array}$ & The influences of the alternative in other economic sectors. \\
\hline & $\begin{array}{l}\text { C } 4.2 \text { Generated } \\
\text { Revenues }\end{array}$ & Incomes that the city will get from new activities. \\
\hline & $\begin{array}{l}\text { C } 4.3 \text { Required } \\
\text { investment }\end{array}$ & $\begin{array}{l}\text { The required capital to implement and support these } \\
\text { alternatives. }\end{array}$ \\
\hline & C 4.4 Tax Policy & Compatibility of new activities with tax benefits. \\
\hline \multirow{5}{*}{$\begin{array}{l}\text { C. } 5 \text { Political- } \\
\text { Administrative }\end{array}$} & $\begin{array}{l}\text { C } 5.1 \text { Compatibility } \\
\text { with the city's vision }\end{array}$ & $\begin{array}{l}\text { Affinity with local, regional and national projects and } \\
\text { programs. }\end{array}$ \\
\hline & $\begin{array}{l}\text { C } 5.2 \text { Institutional } \\
\text { support }\end{array}$ & $\begin{array}{l}\text { Governability framework for the implementation of each } \\
\text { alternative. }\end{array}$ \\
\hline & $\begin{array}{l}\text { C } 5.3 \text { Compatibility } \\
\text { with land-use, existing } \\
\text { plans and regulations } \\
\end{array}$ & $\begin{array}{l}\text { Compatibility with legal regulations, controls or } \\
\text { restrictions. }\end{array}$ \\
\hline & $\begin{array}{l}\text { C } 5.4 \text { Estimated time for } \\
\text { development }\end{array}$ & Required period of time to implement each alternative. \\
\hline & $\begin{array}{l}\text { C } 5.5 \text { Responsible and } \\
\text { sustainable management }\end{array}$ & $\begin{array}{l}\text { Opportunity to insert responsible and sustainable policies } \\
\text { into new services. }\end{array}$ \\
\hline
\end{tabular}




\subsubsection{Representation of the evaluation problem as a network model}

Influences among criteria were determined using a relationship matrix. This procedure was carried out during face-to-face meetings with the experts. The final ANP model proposed is shown in Error! Reference source not found.. The bidirectional arrows indicate influences between clusters in both directions. That is to say, the elements in a cluster (i) exert some influence over elements in another cluster (j). Feedback means that there is influence between criteria belonging to the same group.

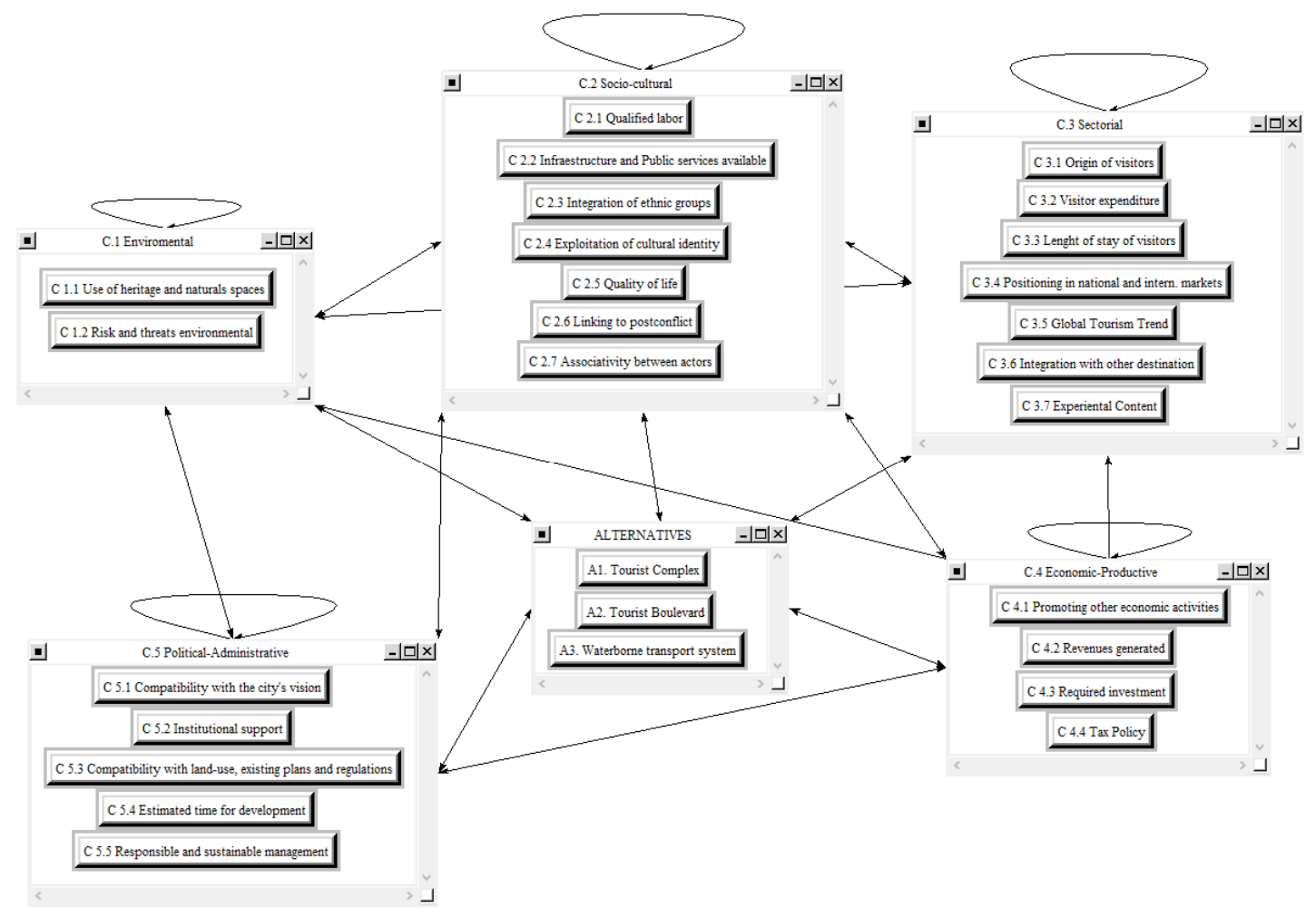

Figure 3. ANP network model of the case study.

\subsubsection{Prioritizing strategies}

Once the model was agreed upon, the ANP questionnaire with the required judgements based on pairwise comparisons was designed and sent to the experts. From the local priorities derived through pairwise comparisons, the results were obtained with the help of Superdecision(C) v.2.0.8. software.

The final limit matrix shows the priority obtained for each criterion, a non-dimensional value that can be considered their relative importance. Since a total amount of 7 people were interviewed, a total of 7 individual results were obtained each of which shows the preference index according to the opinion of one particular expert. Individual judgements' aggregation AIJ was performed using the geometric mean in order to obtain a global judgement (Saaty, 2001). Care was taken to ensure that all pairwise comparison matrices had a CR of less than $10 \%$. In instances where judgments were inconsistent, experts were consulted to reconsider their judgment so that they fall within the acceptable limit. 


\section{RESULTS OBTAINED}

\section{1. $\quad$ Regarding the weights of the criteria}

\subsubsection{At the clusters level}

The cluster weighting provides some important insights into the overall philosophy and underlying participants' conception of what sustainable tourism of the city of Cartagena is. We can analyze their individual decision-making profiles (Error! Reference source not found. and Error! Reference source not found.). Experts 1 and 4 show similar profiles. They both give the highest importance to Environmental (C1) and Sociocultural (C2) aspects and the lowest ones to Economic-Productive (C4) and Politicaladministrative (C5) aspects. So, we could conclude that they show a socioenvironmental profile. On the other hand, experts 5 and 7, the ones who do not belong to the city of Cartagena, give the highest importance to C5 and C4. In this case we could conclude that these two experts present a political-economic profile.

Expert 2 gives the highest importance to C4; followed by C3. So we could define this expert as an economic profile. Expert 6 has a social profile and Expert 3 shows a more balanced profiles.

Table 4. Results obtained for the clusters of criteria

\begin{tabular}{|l|c|c|c|c|c|c|c|c|}
\hline \multicolumn{1}{|c|}{ Cluster } & $\begin{array}{c}\text { Expert 1 } \\
\text { Tourist } \\
\text { Office }\end{array}$ & $\begin{array}{c}\text { Expert 2 } \\
\text { Hotels }\end{array}$ & $\begin{array}{c}\text { Expert 3 } \\
\text { Chamber } \\
\text { of } \\
\text { Commerce }\end{array}$ & $\begin{array}{c}\text { Expert 4 } \\
\text { University }\end{array}$ & $\begin{array}{c}\text { Expert 5 } \\
\text { National } \\
\text { Tourist } \\
\text { Promotion } \\
\text { Office }\end{array}$ & $\begin{array}{c}\text { Expert 6 } \\
\text { Social } \\
\text { group } \\
\text { leader }\end{array}$ & $\begin{array}{c}\text { Expert 7 } \\
\text { International } \\
\text { expert }\end{array}$ & $\begin{array}{c}\text { Group } \\
\text { (AIJ) }\end{array}$ \\
\hline C1Environmental & 0,379 & 0,183 & 0,200 & 0,464 & 0,039 & 0,276 & 0,039 & 0,257 \\
\hline C2 Socio-cultural & 0,333 & 0,052 & 0,200 & 0,209 & 0,076 & 0,397 & 0,113 & 0,228 \\
\hline C3 Sectorial & 0,134 & 0,448 & 0,200 & 0,133 & 0,161 & 0,205 & 0,131 & 0,236 \\
\hline $\begin{array}{l}\text { C4 Economic- } \\
\text { Productive }\end{array}$ & 0,092 & 0,234 & 0,200 & 0,076 & 0,362 & 0,080 & 0,225 & 0,162 \\
\hline $\begin{array}{l}\text { C5 Political- } \\
\text { Administrative }\end{array}$ & 0,062 & 0,082 & 0,200 & 0,119 & 0,362 & 0,042 & 0,492 & 0,117 \\
\hline
\end{tabular}




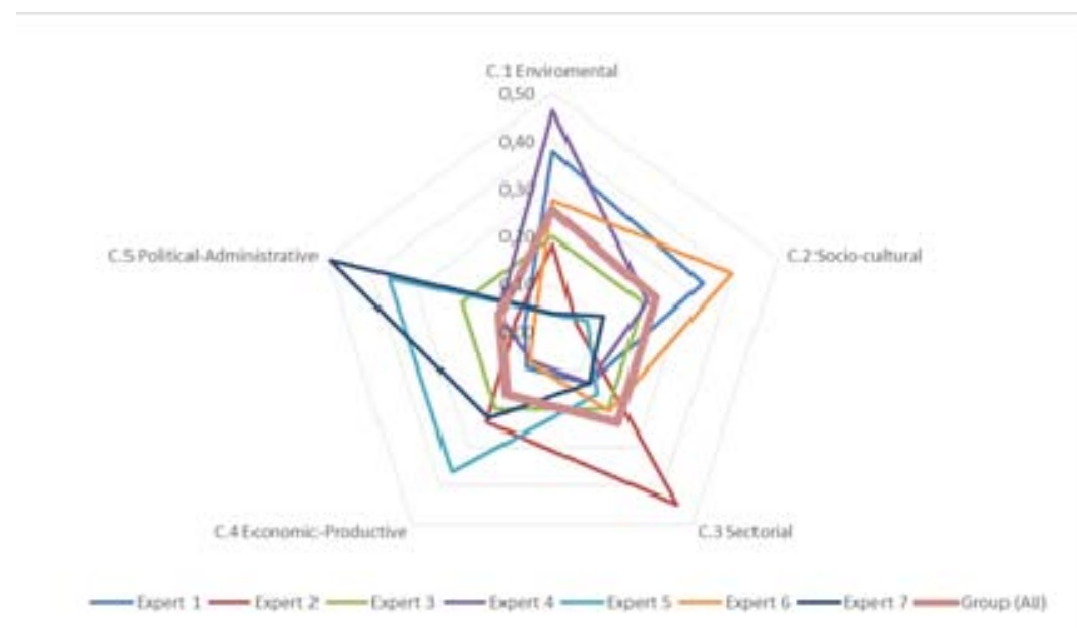

Figure 4. Cluster results according to different experts and global result

\subsubsection{At the criteria level}

From these results the main conclusion we can highlight is that the most relevant criterion for all the experts is C1.1 Use of Heritage and natural spaces (16,4\%) followed by C1.2 Environmental risk and threats (10\%)(see Error! Reference source not found. to observe the differences). Following in importance we can observe a group of criteria formed by C5.5 Responsible and sustainable management, C3.6. Integration with other destinations, C2.7 Associativity between actors, C5.3 Compatibility with land-use, existing plans and regulations, C4.1 Promoting other economic activities, C4.3 Required investment and C5.2 Institutional support, which also have an importance of between 5 and $8 \%$. The least important criteria have an importance of $1 \%$ or less (Error! Reference source not found.).

In general, criteria from the Environmental (A1) cluster are more valued and criteria from the Sectorial (A3) are less valued.

Table 5. Results obtained for the criteria

\begin{tabular}{|l|c|c|c|c|c|c|c|c|}
\multicolumn{1}{l|}{} & $\begin{array}{c}\text { Expert } \\
1\end{array}$ & $\begin{array}{c}\text { Expert } \\
2\end{array}$ & $\begin{array}{c}\text { Expert } \\
3\end{array}$ & $\begin{array}{c}\text { Expert } \\
4\end{array}$ & $\begin{array}{c}\text { Expert } \\
5\end{array}$ & $\begin{array}{c}\text { Expert } \\
6\end{array}$ & $\begin{array}{c}\text { Expert } \\
7\end{array}$ & $\begin{array}{c}\text { Group } \\
\text { (AIJ) }\end{array}$ \\
\hline C1.1 Use of heritage and naturals spaces & 0,198 & 0,185 & 0,129 & 0,196 & 0,136 & 0,166 & 0,154 & 0,164 \\
C1.2 Environmental risk and threats & 0,093 & 0,062 & 0,124 & 0,119 & 0,066 & 0,097 & 0,057 & 0,100 \\
\hline C2.1 Qualified labor & 0,021 & 0,003 & 0,019 & 0,011 & 0,003 & 0,037 & 0,005 & 0,016 \\
C2.2 Available infrastructure and Public & 0,012 & 0,026 & 0,023 & 0,032 & 0,037 & 0,025 & 0,035 & 0,025 \\
services & 0,029 & 0,031 & 0,026 & 0,047 & 0,026 & 0,071 & 0,051 & 0,041 \\
C2.3 Integration of ethnic groups & 0,063 & 0,041 & 0,027 & 0,044 & 0,034 & 0,041 & 0,016 & 0,041 \\
C2.4 Exploitation of cultural identity & 0,043 & 0,020 & 0,047 & 0,027 & 0,033 & 0,035 & 0,017 & 0,037 \\
C2.5 Quality of life & 0,018 & 0,005 & 0,016 & 0,003 & 0,003 & 0,012 & 0,002 & 0,010 \\
C2.6 Linking to postconflict & 0,064 & 0,039 & 0,054 & 0,050 & 0,043 & 0,056 & 0,064 & 0,052 \\
C2.7 Associativity between actors & 0,006 & 0,005 & 0,007 & 0,002 & 0,003 & 0,005 & 0,001 & 0,006 \\
\hline C3.1 Origin of visitors & 0,016 & 0,030 & 0,010 & 0,004 & 0,007 & 0,012 & 0,022 & 0,013 \\
C3.2 Visitor expenditure & 0,011 & 0,017 & 0,013 & 0,005 & 0,012 & 0,016 & 0,015 & 0,015 \\
C3.3 Lenght of stay of visitors & & & &
\end{tabular}


Version del autor

Pre-print

\begin{tabular}{|l|c|c|c|c|c|c|c|c|}
\cline { 2 - 8 } \multicolumn{1}{c|}{} & Expert & Expert & Expert & Expert & Expert & Expert & Expert & Group \\
C3.4 Positioning in nat. and intern. markets & 1 & 2 & 3 & 4 & 5 & 6 & 7 & (AIJ) \\
\cline { 2 - 9 } C3.5 Global Tourism Trend & 0,005 & 0,016 & 0,008 & 0,006 & 0,014 & 0,007 & 0,004 & 0,011 \\
C3.6 Integration with other destination & 0,010 & 0,048 & 0,033 & 0,029 & 0,027 & 0,032 & 0,010 & 0,032 \\
C3.7 Experiental Content & 0,053 & 0,064 & 0,042 & 0,045 & 0,061 & 0,061 & 0,051 & 0,054 \\
\hline C4.1 Promoting other economic activities & 0,045 & 0,073 & 0,049 & 0,045 & 0,032 & 0,027 & 0,052 & 0,044 \\
C4.2 Generated Revenues & 0,050 & 0,040 & 0,045 & 0,041 & 0,047 & 0,053 & 0,035 & 0,050 \\
C4.3 Required investment & 0,029 & 0,055 & 0,036 & 0,010 & 0,033 & 0,011 & 0,043 & 0,026 \\
C4.4 Tax Policy & 0,028 & 0,053 & 0,042 & 0,062 & 0,075 & 0,041 & 0,057 & 0,049 \\
\hline C5.1 Compatibility with the city's vision & 0,006 & 0,006 & 0,020 & 0,004 & 0,040 & 0,002 & 0,019 & 0,009 \\
C5.2 Institutional support & 0,018 & 0,033 & 0,040 & 0,026 & 0,030 & 0,022 & 0,046 & 0,027 \\
C5.3 Compatibility with land-use, existing & 0,046 & 0,041 & 0,047 & 0,039 & 0,094 & 0,041 & 0,087 & 0,047 \\
plans and regulations & 0,067 & 0,045 & 0,058 & 0,052 & 0,056 & 0,042 & 0,068 & 0,051 \\
C5.4 Estimated time for development & 0,003 & 0,008 & 0,014 & 0,008 & 0,013 & 0,004 & 0,019 & 0,008 \\
C5.5 Responsible and sustainable manag. & 0,066 & 0,054 & 0,072 & 0,092 & 0,073 & 0,081 & 0,069 & 0,075 \\
\hline
\end{tabular}

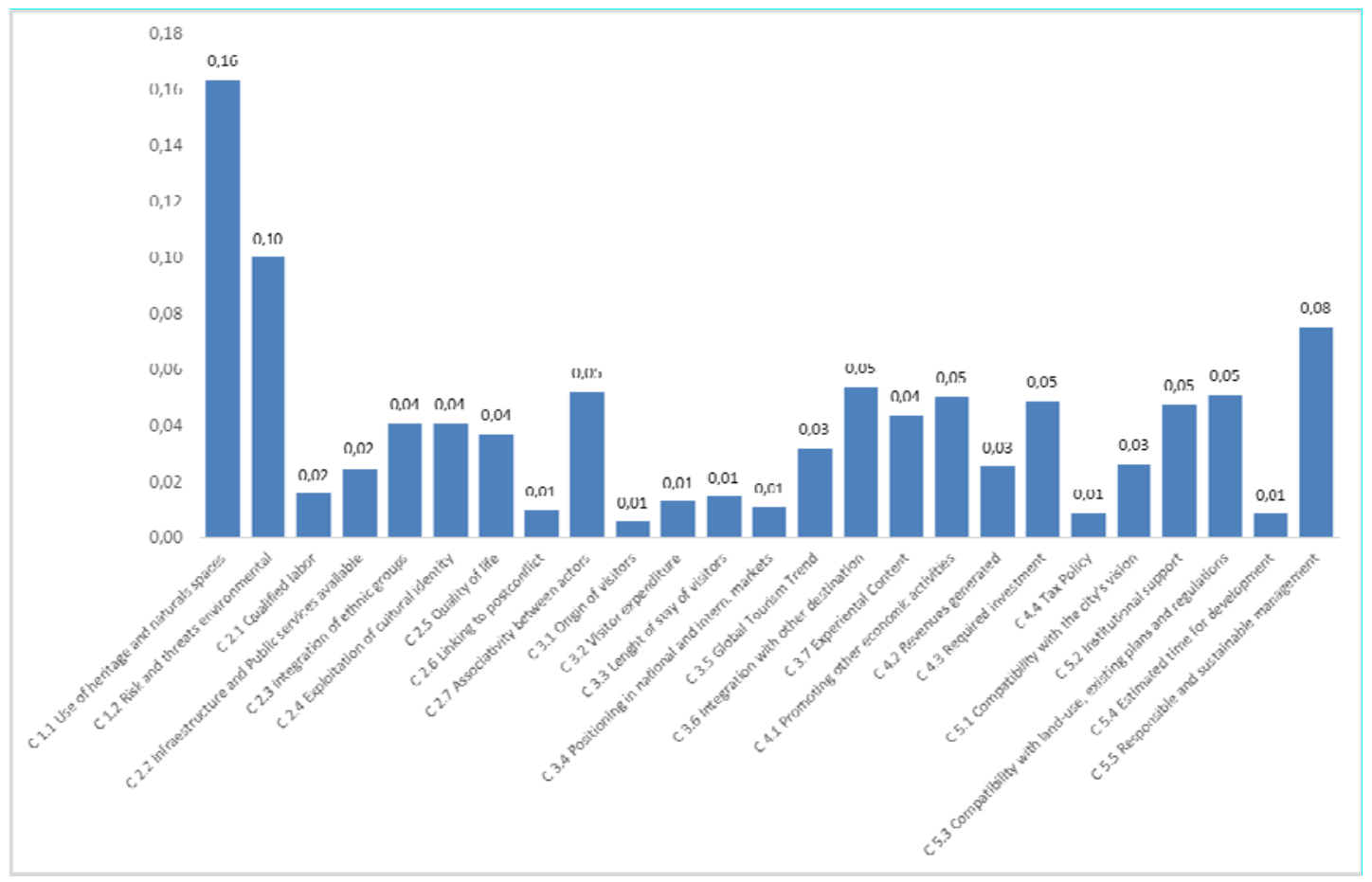

Figure 5. Group results for all the criteria

\subsubsection{Regarding the ranking of the alternatives}

We can conclude that although the different experts show very different ranking preference of the three alternatives that have been analyzed (Error! Reference source not found. and Error! Reference source not found.), when we aggregate the results as a group, the results indicate that the preferred alternative to be implemented is $A 3$. Waterbourne transport system (45\%), followed by A1. Tourist Complex (34\%). 
The Waterborne transport system has been positively valued due to the importance assigned to the criterion related to Use of Heritage and natural spaces, thus its aim is to develop a network of public transportation system using the water resources available around the city, and connecting insular and continental zones.

Table 6. Results obtained for the alternatives

\begin{tabular}{|l|c|c|c|c|c|c|c|c|}
\hline & $\begin{array}{c}\text { Expert } \\
1 \\
\text { Tourist } \\
\text { Office }\end{array}$ & $\begin{array}{c}\text { Expert } \\
2 \\
\text { Hotels }\end{array}$ & $\begin{array}{c}\text { Expert 3 } \\
\text { Chamber } \\
\text { of } \\
\text { Commerce }\end{array}$ & $\begin{array}{c}\text { Expert 4 } \\
\text { University } \\
\text { A }\end{array}$ & $\begin{array}{c}\text { Expert 5 } \\
\text { National } \\
\text { Tourist } \\
\text { Promotion } \\
\text { Office }\end{array}$ & $\begin{array}{c}\text { Expert } \\
6 \\
\text { Social } \\
\text { group } \\
\text { leader }\end{array}$ & $\begin{array}{c}\text { Expert 7 } \\
\text { International } \\
\text { expert }\end{array}$ & $\begin{array}{c}\text { Group } \\
\text { (AIJ) }\end{array}$ \\
\hline $\begin{array}{l}\text { A1. Tourist Complex } \\
\text { A2. Tourist Boulevard }\end{array}$ & 0,359 & 0,440 & 0,347 & 0,427 & 0,190 & 0,375 & 0,561 & 0,344 \\
$\begin{array}{l}\text { A3. Waterborne } \\
\text { transport system }\end{array}$ & 0,290 & 0,330 & 0,442 & 0,351 & 0,474 & 0,538 & 0,257 & 0,449 \\
\hline
\end{tabular}

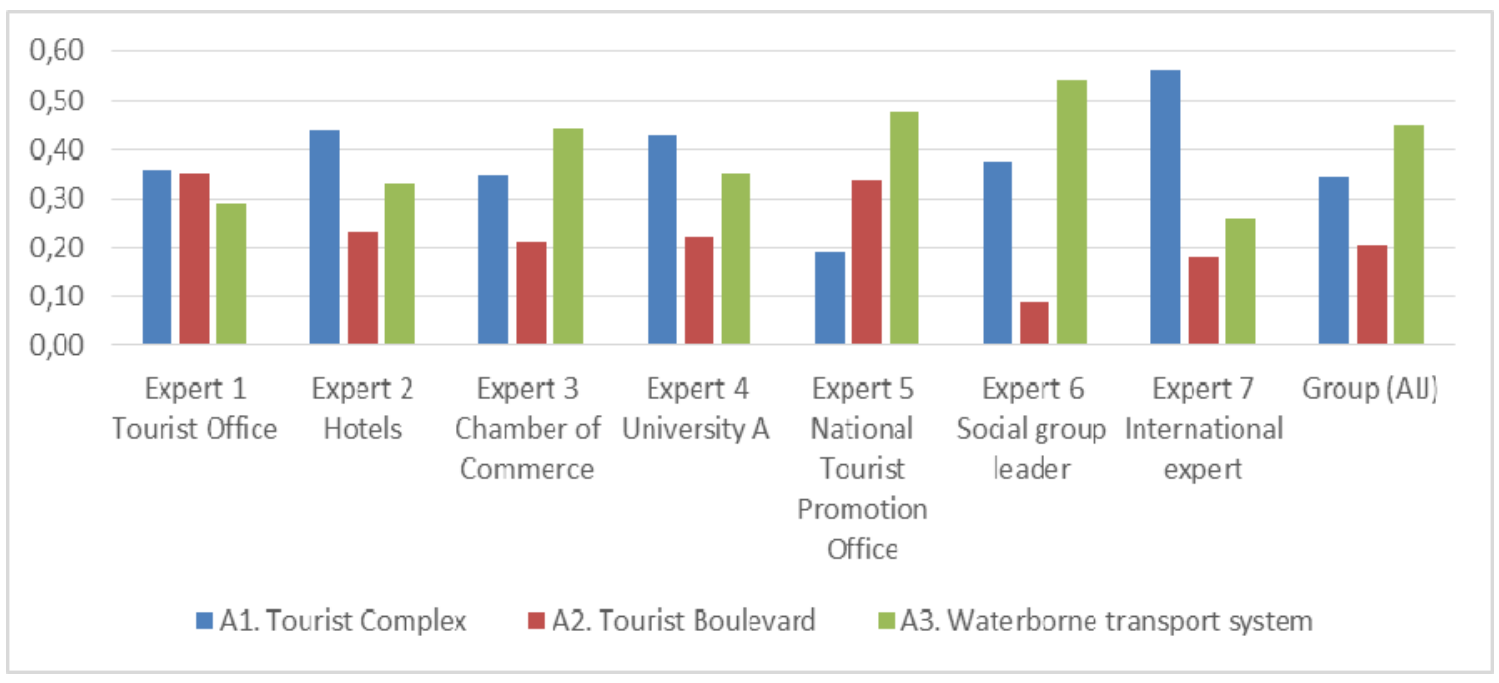

Figure 6. Alternatives

\section{CONCLUSIONS}

Regarding the experts' selection process with SNA

We used SNA to identify and take account of the actors involved in or affected by the tourist sector in Cartagena de Indias (Colombia). Individual values were obtained through the centrality measures. The betweenness results allowed us to determine an individual value of the influence of each actor in order to involve the most influential stakeholders as decision makers (experts).

The application of SNA also offered some insights about how consolidated the sector is. On one hand, we found out that some associations are less representative that expected e.g. Colombian Association of Micro, Small and Medium Enterprises, which came out as an unexpected result. Also others actors such as The Nautical Association were not 


\section{Version del autor \\ Pre-print}

mentioned either. On the other hand, it was also surprising that Tour Operator A (A24) came out as very prominent in front of the rest of tour operators.

\section{Regarding the alternatives prioritization process with ANP}

The variety of the results obtained for the individual ranking of the alternatives shows the differences in perception and attitude among the stakeholders. In the final aggregated ranking A3. Waterbourne transport system has the highest level of preference. The use of ANP allowed to encourage participation.

\section{Regarding the general satisfaction with the process}

The results obtained were presented to the experts. They all agreed that the prioritization process carried out allowed the reduction of debates, controversy and contradictions typical in other types of decision-making sessions. They also stressed that the tourist development plan that was finally selected would improve the touristic offer of the city and would also provide an interesting mobility offer for the inhabitants and tourists, thus, promoting sustainable development in line with global trends.

The combination of SNA-ANP techniques for prioritization of strategic plans allowed transparency and participation. We can conclude that we have brought some light on the issue of solving problems related to participative planning processes.

As future lines of development, we suggest to integrate the SNA-ANP model with other tools such as Geographic Information Systems (GIS), in order to improve the decision making process.

Finally, the authors of this paper suggest the Cartagena Local Administration to further promote this participative approach.

\section{REFERENCES}

A. Eldrandaly K, A. AL-Amari M. An Expert GIS-Based ANP-OWA Decision Making Framework for Tourism Development Site Selection. Int J Intell Syst Appl. 2014;6(7):1-11

Ahmedi L, Rrmoku K, Sylejmani K, Shabani D. A bimodal social network analysis to recommend points of interest to tourists. Soc Netw Anal Min. 2017;7(1):14.

Akbari N, Irawan CA, Jones DF, Menachof D. A multi-criteria port suitability assessment for developments in the offshore wind industry. Renew Energy. 2017; 102:118-133.

Alcaldía Distrital de Cartagena de Indias D. T. y C. Plan de Desarrollo "Primero La Gente" 2016 - 2019.; 2016. Accessed March 15, 2017.

Alcaldía Distrital de Cartagena de Indias D. T. y C. Plan Sectorial del Turismo de Cartagena de Indias. 2014:1-92. Accessed March 15, 2017. 
Alves FL, Sousa LP, Almodovar M, Phillips MR. Integrated Coastal Zone Management (ICZM): A review of progress in Portuguese implementation. Reg Environ Chang. 2013;13(5):1031-1042.

Aminu M, Matori AN, Yusof KW, Malakahmad A, Zainol RB. Analytic network process (ANP)-based spatial decision support system (SDSS) for sustainable tourism planning in Cameron Highlands, Malaysia. Arab J Geosci. 2017;10(13):286.

Aminu M, Matori A-N, Yusof KW, Zainol RB. A Framework for sustainable tourism planning in johor Ramsar sites, Malaysia: A geographic information system (GIS) based analytic network process (ANP) approach. Res J Appl Sci Eng Technol. 2013;6(3):417422.

Arsić S, Nikolić D, Živković Ž. Hybrid SWOT - ANP - FANP model for prioritization strategies of sustainable development of ecotourism in National Park Djerdap, Serbia. For Policy Econ. 2017;80:11-26.

Barba-Romero S, Pomerol J-C. Decisiones Multicriterio: Fundamentos Teóricos Y Utilización Práctica. Universidad Alcalá de Henares; 1997. Accessed January 12, 2018.

Bars M Le, Grusse P Le. Use of a decision support system and a simulation game to help collective decision-making in water management. Comput Electron Agric. 2008;62(2):182-189.

Belton V, Stewart TJ. Multiple Criteria Decision Analysis. Boston, MA: Springer US; 2002.

Berzina I, Grizane T, Jurgelane I. The tourism service consumption model for the sustainability of the special protection areas. Procedia Comput Sci. 2015;43(C):62-68.

Biggs S, Matsaert H. An actor-oriented approach for strengthening research and development capabilities in natural resource systems. Public Adm Dev. 1999;19(3):231262.

Bodin Ö, Crona BI, Ernstson H. Social networks in natural resource management: what is there to learn from a structural perspective? Ecol Soc. 2006;11(2):r2.

Bodin Ö, Crona BI. The role of social networks in natural resource governance: What relational patterns make a difference? Glob Environ Chang. 2009;19(3):366-374.

Bonzanigo L, Giupponi C, Balbi S. Sustainable tourism planning and climate change adaptation in the Alps: a case study of winter tourism in mountain communities in the Dolomites. J Sustain Tour. 2016;24(4):637-652.

Bramwell B. Theoretical activity in sustainable tourism research. Ann Tour Res. 2015;54:204-218.

Brugha R, Varvasovszky Z. Stakeholder analysis: a review. Health Policy Plan. 2000;15(3):239-246.

Bryson JM. What to do when stakeholders matter. Public Manag Rev. 2004;6(1):21-53.

Ceccato L, Giannini V, Giupponi C. Participatory assessment of adaptation strategies to flood risk in the Upper Brahmaputra and Danube river basins. Environ Sci Policy. 2011;14(8):1163-1174.

Chen C-L, Bau Y-P. Establishing a multi-criteria evaluation structure for tourist beaches in Taiwan: A foundation for sustainable beach tourism. Ocean Coast Manag. 2016;121:88-96. 
Chen SH, Chen CM, Lee HT. Tourism development planning using analytic network process. Int J Leis Tour Mark. 2009;1(1):70.

Comisión Regional de Competitividad de Cartagena y Bolívar. Plan Regional de Competitividad Cartagena Y Bolívar 2008 - 2032.; 2010. Accessed March 15, 2017.

Corpoturismo. Retos Y Realidades. El Sector Turístico En Cartagena de Indias. Cartagena de Indias; 2015. Accessed Febrary 15, 2017.

Dvarskas A. Dynamically linking economic models to ecological condition for coastal zone management: Application to sustainable tourism planning. J Environ Manage. 2017;188:163-172.

Elgin D, Weible C. A Stakeholder Analysis of Colorado Climate and Energy Issues Using Policy Analytical Capacity and the Advocacy Coalition Framework. Rev Policy Res. 2013;30(1):114-133.

García-Melón M, Gómez-Navarro T, Acuña-Dutra S. A combined ANP-delphi approach to evaluate sustainable tourism. 2012;34:41-50.

Garcia-Melon M, Gomez-Navarro T, Acuna-Dutra S. An ANP approach to assess the sustainability of tourist strategies for the coastal national parks of Venezuela. Technol Econ Dev Econ. 2010;16(4):672-689.

Glicken J. Getting stakeholder participation "right": a discussion of participatory processes and possible pitfalls. Environ Sci Policy. 2000;3(2000):305-310.

Goosen H, Janssen R, Vermaat JE. Decision support for participatory wetland decisionmaking. Ecol Eng. 2007;30(2):187-199.

Groselj P, Stirn LZ. The environmental management problem of Pohorje, Slovenia: A new group approach within ANP - SWOT framework. J Environ Manage. 2015;161:106-112.

Hanneman RA, Riddle M. Introduction to Social Network Methods. Riverside: University of California, Riverside; 2005.

Hjalager AM. A review of innovation research in tourism. Tour Manag. 2010;31(1):112.

Janssen MA, Goosen H, Omtzigt N. A simple mediation and negotiation support tool for water management in the Netherlands. Landsc Urban Plan. 2006;78(1-2):71-84.

Jeong JS, García-Moruno L, Hernández-Blanco J, Jaraíz-Cabanillas FJ. An operational method to supporting siting decisions for sustainable rural second home planning in ecotourism sites. Land use policy. 2014;41:550-560.

Le Pira M, Ignaccolo M, Inturri G, Pluchino A, Rapisarda A. Modelling stakeholder participation in transport planning. Case Stud Transp Policy. 2016;4(3):230-238.

Liu C-HS, Chou S-F. Tourism strategy development and facilitation of integrative processes among brand equity, marketing and motivation. Tour Manag. 2016;54:298308.

Loken E. Use of multicriteria decision analysis methods for energy planning problems. Renew Sustain Energy Rev. 2007;11(7):1584-1595.

Mariani MM, Buhalis D, Longhi C, Vitouladiti O. Managing change in tourism destinations: Key issues and current trends. J Destin Mark Manag. 2014;2(4):269-272. 
Mitchell RK, Agle BR, Wood DJ. Toward a Theory of Stakeholder Identification and Salience: Defining the Principle of Who and What Really. 2009;22(4):853-886.

Mok KY, Shen GQ, Yang RJ. Addressing stakeholder complexity and major pitfalls in large cultural building projects. Int J Proj Manag. 2017;35(3):463-478.

O'Toole K, Keneley M, Coffey B. The participatory logic of coastal management under the project state: Insights from the Estuary Entrance Management Support System (EEMSS) in Victoria, Australia. Environ Sci Policy. 2013;27:206-214.

Peris J, García-Melón M, Gómez-Navarro T, Calabuig C. Prioritizing Local Agenda 21 Programmes using Analytic Network Process: A Spanish Case Study. Sustain Dev. 2013;21(5):338-352.

Prell C, Hubacek K, Reed M. Stakeholder Analysis and Social Network Analysis in Natural Resource Management. Soc Nat Resour. 2009;22(6):501-518.

Ramzan N, Degenkolbe S, Witt W. Evaluating and improving environmental performance of HC's recovery system: A case study of distillation unit. Chem Eng J. 2008;140(1):201-213.

Reed MS, Graves A, Dandy N, et al. Who's in and why? A typology of stakeholder analysis methods for natural resource management. $J$ Environ Manage. 2009;90(5):1933-1949.

Saaty TL. How to make a decision: The analytic hierarchy process. Eur J Oper Res. 1990;48(1):9-26.

Saaty TL. The Analytic Network Process: Decision Making with Dependence and Feedback. RWS Publications; 2001.

Saint Ville AS, Hickey GM, Phillip LE. How do stakeholder interactions influence national food security policy in the Caribbean? The case of Saint Lucia. Food Policy. 2017;68:53-64.

Šijanec M, Žarnić R, Šelih J. Multicriterial sustainability assessment of residential buildings. Technol Econ Dev Econ. 2009;15(4):612-630.

Sólnes J. Environmental quality indexing of large industrial development alternatives using AHP. Environ Impact Assess Rev. 2003;23(3):283-303.

Wang X, Li, Xiang RobWang, X., Li, X. R., Zhen, F., \& Zhang, J. (2016). How smart is your tourist attraction?: Measuring tourist preferences of smart tourism attractions via a FCEM-AHP and IPA approach. Tour Manag. 2016;54:309-320.

Wasserman S, Faust K. Social Network Analysis. 15th print. New York: Cambridge University Press; 2007.

World Tourism Organization UNWTO. Panorama OMT del turismo internacional. Annu Rep. 2014:12.

World Tourism Organization UNWTO. UNWTO Annual Report 2016. (UNWTO, ed.). Madrid: UNWTO; 2017.

Yamaki K. Applying social network analysis to stakeholder analysis in Japan's natural resource governance: Two endangered species conservation activity cases. J For Res. 2017;22(2):83-90.

Yang RJ. An investigation of stakeholder analysis in urban development projects: Empirical or rationalistic perspectives. Int J Proj Manag. 2014;32(5):838-849. 